DOI: https://doi.org/10.53754/iscs.v1i1.2

\title{
TINJAUAN MAȘLAHAH HִIFZ AL-MĀL TERHADAP PELAKSANAAN AKAD KERJASAMA BAGI HASIL DI DESA SUMBERDODOL KECAMATAN PANEKAN KABUPATEN MAGETAN
}

\section{REVIEW MAȘLAHAH ḤIFZ AL-MĀL ON THE IMPLEMENTATION OF THE COOPERATION AGREEMENT FOR PRODUCTS IN SUMBERDODOL VILLAGE, PANEKAN DISTRICT, MAGETAN REGENCY}

\author{
Aima Mar'atus Solihah \\ Institut Agama Islam Negeri Ponorogo \\ Email; aimamara021198@gmail.com
}

\begin{abstract}
This research purpose: 1) To find out the maslahah and mafsadah elements of implementing the production sharing agreement in Sumberdodol Village Panekan District Magetan Regency. 2) To determine the level of maslahah hifz al-mal on the production sharing agreement in Sumberdodol Village Panekan District Magetan Regency. The type of research conducted by the author is field research using qualitative methods, while the data collection techniques used are interviews and observation. From this research, it can be concluded that 1) The maslahah element in implementing the production sharing agreement in Sumberdodol village is that the garden owner has prospered the farm cultivator by providing a good job. Farmers can work to supplement their family's needs. While the element of mafsadah is the distribution of results that is not under the agreement, and the cultivator does not yet know the deadline for the end of the collaboration. 2) The level of maslahah hifz almal in cooperation for profit-sharing in the village of Sumberdodol is included in the Hajiyah level. Its existence is needed to provide convenience and eliminate difficulties in human life. Because cultivators and gardeners both provide convenience and benefits.
\end{abstract}

Keywords: coorperation, maslahah, hifz al-mal

\section{PENDAHULUAN}

Kerjasama merupakan kegiatan yang sering dilakukan oleh masyarakat pada umumnya. Karena manusia diciptakan oleh Allah Swt. sebagai makhluk sosial yang mana manusia tidak mampu memenuhi kebutuhannya sendiri tanpa bantuan dari manusia yang lain (Mas'adi, 2002). sedangkan untuk memenuhi kebutuhan hidup agar dapat melangsungkan kehidupan, Allah Swt. menyerahkan sepenuhnya kepada manusia sepanjang tidak melewati batas-batas yang telah ditentukan oleh agama (Basyir, 1981). Hubungan manusia dengan manusia yang lainnya dalam literatur hukum Islam disebut muamalat (Mas'adi, 2002).

Terdapat berbagai macam bentuk kerjasama yang dilakukan oleh manusia salah satunya adalah kerjasama pertanian. kegiatan bertani dan berkebun merupakan kegiatan yang legal dalam Islam. Kerjasama dengan cara bagi hasil merupakan salah satu kegiatan muamalah yang sering terjadi di kalangan masyarakat, khususnya dalam bidang pertanian dan perkebunan. Kerjasama secara bagi hasil ini diperbolehkan dalam Islam 
Received: 2021-01-15 Revised: 2021-01-24 Approved: 2021-01-24

baik terhadap barang bergerak maupun tidak bergerak seperti tanah (Sabiq, 2008). Sistem bagi hasil menjadi suatu hal yang penting manakala seseorang mempunyai tenaga kerja tetapi tidak memiliki lahan, sementara yang lain memiliki lahan tetapi tidak memiliki tenaga kerja. Berdasarkan kondisi tersebut maka prinsip bagi hasil dan prinsip tolong menolong merupakan cara efektif untuk menghasilkan lebih banyak tanah yang diolah sehingga menguntungkan kedua pihak (Afzal-ur-Rahman., 1991).

Kerjasama bagi hasil juga dipraktikkan oleh masyarakat Desa Sumberdodol. Desa Sumberdodol adalah desa wisata yang merupakan bagian dari Kecamatan Panekan Kabupaten Magetan. Desa tersebut memiliki banyak kegiatan ekonomi seperti bertani dan berkebun, mayoritas masyarakatnya bekerja sebagai petani dan penggarap kebun untuk menunjang kehidupan keluarga mereka. Sebagian dari masyarakat Desa Sumberdodol memiliki lahan tetapi tidak mampu untuk merawatnya dan yang lainnya tidak memiliki lahan tetapi ingin sekali mengelola lahan pertanian dan perkebunan. Dalam melakukan kerjasama pasti tidak terlepas dari permasalahan-permasalahan yang terjadi antara keduanya. Seperti praktik kerjasama yang dilakukan oleh pemilik kebun dengan penggarap kebun di Desa Sumberdodol, pemilik kebun tersebut menawarkan kerjasama dengan tetangga atau saudara yang mereka percaya untuk mengelola lahan perkebunan miliknya dengan perjanjian ketika panen hasilnya dibagi dengan persentase 50\%:50\% dengan penggarap kebun.

Kerjasama bagi hasil yang dilakukan di Desa Sumberdodol sudah biasa dilaksanakan oleh masyarakat zaman dahulu. Kerjasama antara pemilik kebun dan penggarap kebun dilakukan atas dasar saling tolong menolong dan tanpa adanya paksaan dari pihak mana pun. Dalam praktiknya kerjasama yang dilakukan masyarakat Desa Sumberdodol kesepakatan yang telah dibuat antara pihak pemilik kebun dan penggarap kebun dalam pembagian hasil panen tidak sesuai dengan perjanjian di awal akad. Pemilik kebun tidak ikut serta dalam mengelola kebun tersebut, tetapi pada saat panen tiba pemilik kebun hanya memberikan 40\% dari hasil panen kepada penggarap kebun. Padahal di dalam perjanjian jelas mengatakan bahwa persentase $50 \%$ untuk penggarap kebun. Permasalahan lainnya adalah penggarapan kebun tersebut belum diketahui batas waktunya. Apabila pemilik kebun meminta kebun tersebut maka berakhir pula kerjasama yang mereka lakukan.

Dalam melakukan kerjasama harus menggunakan unsur kemaslahatan diantara keduanya, jangan sampai menimbulkan kemudharatan yang akan mengakibatkan permasalahan yang akan terjadi di kemudian hari. Mașlahah adalah sesuatu yang 
Received: 2021-01-15 Revised: 2021-01-24 Approved: 2021-01-24

mendatangkan kebaikan, faedah, dan guna. Sedangkan kemaslahatan berarti kebaikan, manfaat, dan kepentingan. Mașlaḥah secara umum dapat dicapai melalui dua cara, yaitu pertama, mewujudkan kebaikan atau manfaat. Kedua, menghindari atau mencegah kemudharatan. Lawan dari mașlahah adalah mafsadah yang berarti kerusakan (Nata, 2003). Unsur mașlahah harus mencapai manfaat dan menolak kemudharatan, maksudnya adalah untuk mencapai tujuan shara' yang meliputi menjaga agama, menjaga akal, menjaga jiwa, menjaga keturunan, dan menjaga harta. Setiap hal yang menjaga lima unsur tersebut disebut mașlahah, sedangkan setiap hal yang mengabaikan kelima unsur tersebut disebut mafsadah (Al-Ghazali, 1971).

Menurut hukum Islam sudah seharusnya setiap perjanjian kerjasama dilakukan atas dasar tujuan saling menguntungkan. Dan menjadi keharusan di antara pihak yang berakad dalam kerjasama bagi hasil untuk menjaga hak-hak setiap orang dan kepemilikan hartanya. Setiap perbuatan yang dapat merugikan orang lain dalam muamalah jelas tidak dibenarkan secara syari'at, karena bertentangan dengan hukum Islam dan tujuan-tujuan di dalam maqāṣid al-sharī’ah.

Ketidakadilan dalam pembagian bagi hasil dan tidak adanya kesepakatan tentang berakhirnya akad ini akan menimbulkan beberapa hal yang kurang baik bagi buruh kebun. Pertama, jika kerjasama perkebunan ini sewaktu-waktu ditarik atau dianggap selesai oleh pemilik kebun maka akan berdampak pada hilangnya perkerjaan penggarap kebun. Kedua, Pembagian hasil panen yang tidak sesuai, akan mengakibatkan berkurangnya pendapatan dan keinginan penggarap kebun yang sudah direncanakan sebelumnya terkait hasil dari pekerjaannya mengelola kebun tersebut. Bagi hasil dari penggarapan kebun yang diberikan merupakan sesuatu yang berkaitan untuk menunjang kesejahteraan atau menciptakan kemaslahatan untuk penggarap kebun.

Menurut pernyataan fuqaha, bahwa hukum Islam bertujuan memelihara kemaslahatan manusia, sekaligus untuk menghindari kerusakan (mafsadah). Dalam literatur teori hukum Islam, kemaslahatan diistilahkan sebagai maqāșid al-sharī’ah (Abu Zahrah, 2008). Maqāṣid al-sharī'ah dapat diartikan sebagai tujuan syariah. Maqāṣid juga bisa diartikan sebagai mașlaḥah (Auda, 2010). Yang dimaksud dengan mașlahah adalah menjaga atau memelihara tujuan shara', adapun tujuan shara' ada lima, yaitu: (1) memelihara agama, (2) memelihara jiwa, (3) memelihara akal, (4) memelihara keturunan, dan (5) memelihara harta benda. Setiap sesuatu yang mengandung atau mencakup pemeliharaan atas lima pokok dasar tersebut adalah maṣlahah, dan sebaliknya setiap sesuatu yang mengabaikan lima unsur pokok tersebut disebut 
Received: 2021-01-15 Revised: 2021-01-24 Approved: 2021-01-24

mafsadah (Amin, 2002). Mașlaḥah itu sesungguhnya adalah memelihara dan memperhatikan tujuan-tujuan hukum Islam berupa kebaikan dan kemanfaatan yang dikehendaki oleh hukum Islam, bukan oleh hawa nafsu manusia (Mutakin, 2017). Setiap hal yang menjadi perantara terjaganya lima hal tersebut, dibagi menjadi tiga tingkatan kebutuhan, yaitu (1) ḍarūriyyāt, (2) ḥājiyyāt dan (3) tahsīniyyāt ('Abd al-Mawjud \& Mu'awwad, 1994). Tingkatan Pertama, d̦arūrīyyāt (kebutuhan primer) merupakan sesuatu yang harus ada untuk eksistensi manusia. Secara urutan peringkatnya yaitu: (1) hifẓ al-dīn (menjaga agama), (2) hif z̦ al-nafs (menjaga jiwa), (3) hifẓ al-'aql (menjaga akal), (4) hifẓ al-nasl (menjaga keturunan), dan (5) hifẓ al-māl (menjaga harta). Kelima hal itu disebut ḍarūriyyāt khomsah (ḍarūriyyāt yang lima) (Ushul fiqh jilid 2 / Amir Syarifuddin, 2008). Tingkatan kedua, hājiyyāt (kebutuhan sekunder) adalah hal yang diperlukan oleh manusia untuk mempermudah dalam kehidupan dan menghilangkan kesulitan maupun kesempitan (“FITRAH:Jurnal Kajian Ilmu-ilmu Keislaman," 2018). Tingkatan ketiga, tahsīniyyāt (kebutuhan tersier) adalah sesuatu yang sebaiknya ada untuk memperindah kehidupan ('Abd al-Mawjud \& Mu'awwad, 1994).

Dari kelima maqāșid al-sharī'ah di atas, penelitian ini berfokus pada menjaga harta (hifzz al-māl). Harta merupakan salah satu kebutuhan inti dalam kehidupan. Harta yang baik pastinya berasal dari tangan-tangan orang yang cara memilikinya dari pekerjaan yang dianjurkan oleh agama, seperti bekerja di sawah, pabrik, perdagangan, dan lainnya. Perlindungan harta untuk yang baik ini tampak dalam salah satu hal berikut, yaitu memiliki hak untuk dijaga dari para musuhnya, baik pencurian, perampokan, atau tindakan lain yang memakan harta orang lain (Jauhar \& (Kuwais), 2009).

Pada peringkat d̦arūriyyāt, seorang Muslim harus menjaga hartanya dari memakan harta anak yatim, riba, suap, korupsi, penipuan, dan lainnya dari jalur yang diharamkan (Aprianto, 2017).

Pada peringkat hājiyyāt, misalnya menjauhkan harta kita dari hal-hal yang syubhat. Sedangkan pada peringkat tahsīniyyāt, seperti adanya ketentuan agar menghindari diri dari segala bentuk dari hasil penipuan produk yang erat kaitannya dengan etika bisnis.

Dari uraian latar belakang di atas maka penulis akan menganalisis tentang konsep mașlahah dan mafsadah dari pelaksanaan akad kerjasama bagi hasil dan menganalisis tentang jenis tingkatan yang sesuai dengan kerjasama bagi hasil di Desa Sumberdodol dengan menggunakan teori hịz̧ al-māl. maka judul yang dijadikan bahan penelitian 
Received: 2021-01-15 Revised: 2021-01-24 Approved: 2021-01-24

skripsi ini adalah "Tinjauan Mașlaḥah Ḥifẓ al-Māl Terhadap Pelaksanaan Akad Kerjasama Bagi Hasil di Desa Sumberdodol Kecamatan Panekan Kabupaten Magetan.”

\section{METODE PENELITIAN}

Jenis penelitian yang digunakan adalah penelitian lapangan (field research) yaitu dengan mencari sumber-sumber data langsung terkait mașlahah dan objek yang diteliti di Desa Sumberdodol Kecamatan Panekan Kabupaten Magetan perspektif hifz al-māl. Penulis menggunakan pendekatan kualitatif, pendekatan kualitatif adalah penelitian yang menghasilkan data deskriptif berupa kata-kata tertulis (Gulo, 2002). Dalam penelitian ini lokasi atau daerah yang dijadikan objek penelitian oleh peneliti adalah di Desa Sumberdodol Kecamatan Panekan Kabupaten Magetan. Dalam analisis data ini, data yang telah ditemukan secara akurat berdasarkan fakta di lapangan beserta gambarannya akan dianalisis menggunakan metode kualitatif, yaitu analisis yang berasal dari data yang selanjutnya diteliti berdasarkan teori yang ada dan hasil dari permasalahan di lapangan tersebut akan dideskripsikan menggunakan kata-kata secara tertulis. Metode ini bertujuan untuk mendeskripsikan objek penelitian secara sistematis, faktual, dan akurat terhadap fakta, serta hubungan antara fenomena yang diteliti dengan teori yang ada.

\section{PEMBAHASAN}

Analisis Unsur Maṣlaḥah dan Mafsadah Terhadap Pelaksanaan Akad Kerjasama Bagi Hasil di Desa Sumberdodol Kecamatan Panekan Kabupaten Magetan

Kerjasama yang dilakukan oleh pemilik kebun dan penggarap kebun tersebut dapat dilihat dari unsur mașlahah dan dari unsur mafsadah dalam pelaksanaan kerjasama bagi hasil, yaitu:

1. Dilihat dari segi mașlahah

Dengan melakukan kerjasama antara pemilik kebun dengan buruh kebun tersebut sudah menerapkan prinsip kemaslahatan. Tetapi dalam melaksanakannya pun harus sesuai dengan rukun dan syarat yang telah ditentukan. Dengan mengajak buruh kebun bekerjasama penggarapan kebun tersebut pemilik kebun telah menyejahterakan kehidupan buruh kebun yaitu dengan memberikan pekerjaan yang halal, membantu kebutuhan keluarga buruh kebun. Pemilik kebun telah memberikan manfaat dan kebaikan untuk kebunnya dengan menggarap perkebunan tersebut yang dilakukan oleh buruh kebun, perkebunan miliknya akan terawat dan dapat menghasilkan. Dengan adanya 
Received: 2021-01-15 Revised: 2021-01-24 Approved: 2021-01-24

kerjasama ini masyarakat diharapkan akan terhindar dari keburukan seperti mencuri, riba, dan hal yang dilarang oleh syariat.

Penggarap kebun dalam penggarapan kebun juga terdapat mașlahah/manfaat bagi dirinya, antara lain adalah buruh kebun mendapatkan pekerjaan yang halal, dengan pekerjaan tersebut buruh kebun dapat membantu keluarganya dan orang di sekitarnya. Selain itu, hasil dari kerjasama ini dapat ditabung untuk membeli hewan ternak seperti kambing, dan untuk tabungan apabila ada keadaan mendesak di kemudian hari. Sesuai dengan konsep dari mașlahah itu sendiri adalah mendatangkan atau mewujudkan manfaat dan kebaikan untuk orang lain, dan menolak kerusakan serta untuk mencapai tujuan dari maqāșid al-sharī'ah yaitu memelihara agama, akal, jiwa, keturunan, dan harta. Yang menjaga lima unsur tersebut disebut maṣlaḥah dan sebaliknya yang tidak dapat menjaga lima unsur tersebut disebut mafsadah.

2. Dilihat dari segi mafsadah

Mafsadah merupakan kebalikan dari mașlaḥah, yang berarti kerusakan. Pembahasan pada bab sebelumnya dijelaskan bahwa menolak mafsadah itu merupakan pelengkap dari kewujudan kemaslahatan. Dalam melakukan kerjsasama pasti tidak luput dari persmaslahan atau perselisihan diantara kedua pihak. Sama halnya yang terjadi dalam kerjasama yang dilakukan oleh pemilik kebun dan penggarap kebun di Desa Sumberdodol masih terjadi permasalahanpermasalahan diantara kedua pihak. Unsur mafsadah dalam kerjasama ini adalah dalam pelaksanaannya tidak ada ketentuan kapan berakhirnya akad kerjasama dan tidak bisa berkomitmen dengan perjanjiannya di awal akad tentang pembagian hasil panen yang tidak sesuai. Dapat dikatakan bahwa perjanjian tersebut belum sesuai dengan syarat dalam hukum Islam apabila dilihat dari teori mafsadah pada bab sebelumnya. Karena menolak mafsadah lebih utama daripada menggapai kemaslahatan. Segala bentuk kebaikan dan kemaslahatan harus terus diusahakan, sedangkan semua bentuk mafsadah harus dihindari (Hallaq, 2000). Pembagian hasil panen yang seharusnya didapat oleh buruh kebun ternyata tidak sesuai dan merugikan pihak buruh kebun. Tenaga yang selama ini dikeluarkan oleh buruh kebun seperti mengairi, merawat dan lainnya tidak sesuai dengan hasil yang didapat. Karena mewujudkan kemaslahatan adalah hal yang penting bagi manusia, agar terciptanya kesejahteraan dan salah satunya untuk menghindari kesulitan bagi orang lain terutama dalam hal menjaga harta. 
Received: 2021-01-15 Revised: 2021-01-24 Approved: 2021-01-24

Pemilik kebun dalam mendapatkan hartanya masih mengambil hak dari buruh kebun dengan jalan yang tidak dibolehkan oleh syariat, seperti dijelaskan bahwa dalam Islam dilarang menimbun harta untuk mencegah ketimpangan ekonomi orang lain. Harta tersebut harus dibagikan untuk orang lain khususnya untuk buruh kebun yang sesuai dengan hak buruh kebun dapatkan selama melakukan kerjasama tersebut. Hal ini tidak dibenarkan dalam syariat, karena menolak mudharat harus didahulukan, jika tidak akan menimbulkan kerusakan dan berakibat pada hilangnya manfaat dan keberkahan. Kemudaharatan harus dihilangkan atau ditinggalkan, dengan arti pemilik kebun tidak boleh mengambil harta milik orang lain yaitu buruh kebun, karena akan merugikan orang lain dan telah luput dari maqāṣid al-sharī’ah.

Analisis Tingkatan Maṣlaḥah Ḥifẓ al-Māl Terhadap Pelaksanaan Akad Kerjasama Bagi Hasil di Desa Sumberdodol Kecamatan Panekan Kabupaten Magetan

Menjaga harta (hifž al-māl) merupakan kewajiban untuk memelihara dan menjaga harta benda dengan baik dalam rangka untuk sarana beribadah kepada Allah SWT. Dalam memelihara dan menjaga harta Islam mengharamkan hal-hal yang terkait dengan penipuan, pencurian, penimbunan dan menjalankan aktivitas yang berhubungan dengan riba, karena dalam mendapatkan harta harus diperoleh yang telah disyariatkan yaitu usaha-usaha yang berbasis halal, seperti berdagang dan mengelola industri (Febriadi, 2017).

Dalam pelaksanaan kerjasama perkebunan antara pemilik kebun dengan penggarap kebun di Desa Sumberdodol termasuk ke dalam tingkatan hāāīyāh yang merupakan kebutuhan sekunder yaitu sesuatu yang dibutuhkan bagi kehidupan manusia, tetapi tidak mencapai tingkat ḍarūrī. Seandainya kebutuhan itu tidak terpenuhi dalam kehidupan manusia, tidak akan meniadakan atau merusak kehidupan itu sendiri. Namun demikian, keberadaannya dibutuhkan untuk memberikan kemudahan serta menghilangkan kesukaran dan kesulitan dalam kehidupan manusia, seperti disyariatkannya jual beli, sewa-menyewa, utang-piutang, kerjasama mudarabah dan musaqah, dan lain sebagainya dengan ketentuan bahwa kemaslahatan ḥājīyāh mengikuti kemaslahatan ḍarūrīyah karena ḥājīyāh itu harus mengikuti ḍarūrīyah. Sebaliknya seseorang dilarang melakukan kegiatan yang mubadzir atau terlalu kikir dengan hartanya, karena sikap boros dan kikir dalam hidup akan menjauhkan dirinya dari kemuliaan. 
Received: 2021-01-15 Revised: 2021-01-24 Approved: 2021-01-24

Kebaikan harta akan diperoleh dari usaha-usaha yang telah dianjurkan oleh agama (Jauhar \& (Kuwais), 2009). Termasuk di dalamnya dengan memperhatikan kehalalan dalam mendapatkannya. Perhatian buruh kebun terhadap membelanjakan hasil dari pekerjaannya menjadi penting dipertahankan. Selain karena keberkahan berdasarkan pengalamannya, kesadaran ini secara langsung dijadikan sebagai langkah preventif untuk memberikan contoh kepada kebaikan bagi orang-orang di sekitarnya.

Pemilik kebun yang dalam mendapatkan hartanya dengan mengambil hak milik orang lain menjadikan penggarap kebun mengalami kerugian. Harta yang banyak bukanlah indikator kesuksesan seorang hamba. Kesuksesan dimata Allah SWT hanya dimiliki oleh orang yang tidak dilalaikan oleh harta dan mampu menggunakannya untuk kemanfaatan diri, orang lain serta agama dengan tujuan untuk kebaikan di akhirat kelak. Buruh kebun menyadari bahwa penggunaan harta tidak semata menyangkut masalah dunia melainkan juga akhirat. Hal ini diterapkan dengan tidak berlaku berlebih-lebihan dan menggunakannya sesuai kebutuhan.

\section{KESIMPULAN}

Unsur mașlahah dalam pelaksanaan akad kerjasama bagi hasil di Desa Sumberdodol yaitu dengan penggarapan kebun ini dapat membantu buruh kebun dalam memberikan pekerjaan dan mendapatkan penghasilan yang halal. Karena dengan melakukan kerjasama ini kebun milik pemilik kebun akan terawat dengan baik dan akan mendapatkan keuntungan. Karena menciptakan kemaslahatan akan menumbuhkan kesejahteraan dan kemuliaan dengan cara memberikan kesenangan/kebaikan untuk manusia lain. Selain mașlahah juga terdapat unsur mafsadah, yaitu dengan pembagian hasil yang tidak sesuai dan jangka waktu penggarapan yang tidak diketahui akan berakibat pada hilangnya kesejahteraan, dan penghasilan yang seharusnya didapat menjadi berkurang, karena pemilik kebun cenderung mengabaikan unsur-unsur mașlaḥah. Dengan demikian, belum sesuai dengan unsur mașlaḥah.

Tingkatan mașlahah hifz al-māl dalam pelaksanaan kerjasama bagi hasil di Desa Sumberdodol masuk ke dalam tingkatan ḥājīyāh, keberadaannya dibutuhkan untuk memberikan kemudahan serta menghilangkan kesukaran dan kesulitan dalam kehidupan manusia. Karena penggarap kebun dan pemilik sama-sama memberikan kemudahan dan manfaat. Pemilik kebun memberikan kemudahan kepada penggarap kebun dengan memberikan perkerjaan yang halal, dan penggarap kebun memberikan kemudahan kepada pemilik kebun dengan menggarap perkebunan miliknya dengan baik. 
Vol. 1 No. 1 (2021): Islamic Science, Culture, and Social Studies

Received: 2021-01-15 Revised: 2021-01-24 Approved: 2021-01-24 
Received: 2021-01-15 Revised: 2021-01-24 Approved: 2021-01-24

\section{DAFTAR PUSTAKA}

'Abd al-Mawjud, 'Adil Ahmad., \& Mu'awwad, 'Ali Muhammad. (1994). القواعد الصغرى : " الفو ائد "في مختصر القواعد."Dar al-Jil : Maktabah al-Sanah.

Abu Zahrah, M. (2008). Ushul Fiqih (12th ed.). Pustaka Firdaus.

Afzal-ur-Rahman. (1991). Doktrin ekonomi Islam. DBP.

Al-Ghazali. (1971). l Mustasfa min Ilmi al Ushul. Syirkah al Tiba'ah al Fanniyah al Muntahidah.

Amin, A. (2002). "Paradigma Alternatif Pengembangan Usul Fiqh", dalam Mazhab Jogja: Menggagas Paradigma Ushul Fiqh Kontemporer. R-RUZZ Press.

Aprianto, N. E. K. (2017). The concept of wealth in the view of maqashid al-sharia. Journal of Islamic Economics Lariba; Volume 3 Issue 2 July-December 2017. https://journal.uii.ac.id/JIELariba/article/view/9655

Auda, J. (2010). Maqasid al-shariah as philosophy of Islamic law : a systems approach. Islamic Book Trust.

Basyir, A. A. (1981). Garis besar sistem ekonomi Islam. Bagian Penerbitan Fakultas Ekonomi, Universitas Gadjahmada.

Febriadi, S. R. (2017). APLIKASI MAQASHID SYARIAH DALAM BIDANG PERBANKAN SYARIAH. Amwaluna: Jurnal Ekonomi Dan Keuangan Syariah, 1(2), 231-245. https://doi.org/10.29313/amwaluna.v1i2.2585

FITRAH:Jurnal Kajian Ilmu-ilmu Keislaman. (2018). FITRAH FITRAH:Jurnal Kajian Ilmu-ilmu Keislaman, 4(1).

Gulo, W. (2002). Metodologi penelitian. Penerbit PT Grasindo.

Hallaq, W. B. (2000). Sejarah Teori Hukum Islâm: Pengantar Ushul Fiqh Madzhab Sunni, (H. bin W. E., Kusnadiningrat dan Abdul (Ed.)). PT. Raja Grafindo Persada.

Jauhar, A. A.-M. H., \& (Kuwais), K. (2009). Maqashid syariah. AMZAH.

Mas'adi, G. A. (2002). Fiqh muamalah kontekstual. PT RajaGrafindo Persada.

Mutakin, A. (2017). Teori Maqshid Al Syariah dan Hubungannya dengan Metode Istinbath Hukum. Universitas Syiah Kuala. http://jurnal.unsyiah.ac.id/kanun/article/view/7968

Nata, A. (2003). Masail al-fiqhiyah. Kencana.

Sabiq, al-S. (2008). Fiqih sunnah. Pena Pundi Aksara. 
Received: 2021-01-15 Revised: 2021-01-24 Approved: 2021-01-24

Ushul fiqh jilid 2 / Amir Syarifuddin. (2008). Jakarta: Kencana. http://opac.library.um.ac.id/oaipmh/../index.php?s_data=bp_buku\&s_field=0\&mod=b\& cat $=3$ \&id $=34251$

\section{Copyright (c) 2021 Aima Mar'atus Solihah}

(c) (7) (8) This work is licensed under a Creative Commons Attribution-NonCommercial 4.0 International License. 